\title{
A literatura e o processo colonizador em Maíra, de Darcy Ribeiro
}

\author{
Maíra Basso Motta ${ }^{1}$
}

\begin{abstract}
RESUMO: A pesquisa procura investigar na obra de Darcy Ribeiro, Maíra, questões relacionadas à colonização brasileira, que estão formalizadas em sua estrutura. Partindo de uma análise histórica da colonização brasileira e das conseqüências do encontro do homem branco com o indígena, perpassando pela influência da religião católica na cultura dos nativos - que se configurou como arma ideológica para justificar a colonização e a barbárie que se impôs aos índios.
\end{abstract}

ABSTRACT: The research investigates the work of Darcy Ribeiro, Maíra, issues related to the Brazil's colonization, which are formalized in structure. From a historical analysis of Brazil's colonization and the consequences of man's encounter between indigenous and white, it's passing through the influence of the Catholic culture of the natives - which appeared as an ideological weapon to justify the colonization and barbarism which prevailed among the indians.

PALAVRAS-CHAVE: Darcy Ribeiro; colonização; barbárie; literatura

KEYWORDS: Darcy Ribeiro; colonization; barbarism; literature

\section{Introdução}

Esta pesquisa de produção em Iniciação Científica é parte de um projeto desenvolvido na Universidade de Brasília pelo grupo Literatura e Modernidade Periférica, composto por alunos da graduação e da pós-graduação, mestres, doutores e pós-doutores, ligados à Universidade.

A motivação para a realização deste projeto é a necessidade de aprofundar a compreensão da literatura como produção estética e, ao mesmo tempo, histórico-social. Isto não significa que a literatura esteja diretamente ligada aos fatos históricos, pois o trabalho literário pode recriar a realidade segundo as leis do próprio fazer literário, mas o trabalho literário, sendo produção humana, está ligado ao processo social, que não é necessariamente representado de forma direta na literatura, mas que no processo de criação se internaliza na estrutura da obra.

Baseado nisto, este projeto procura investigar na obra de Darcy Ribeiro, Maíra, questões relacionadas à colonização brasileira, que estão formalizadas em sua estrutura.

\footnotetext{
${ }^{1}$ Graduanda em Letras-Português (Bacharelado) pela Universidade de Brasília - UnB Pesquisa com título homônimo, pelo Programa de Iniciação Científica (UnB/CNPq) e-mail: mairabasso87@gmail.com
} 
Partindo de uma análise histórica da colonização brasileira e das conseqüências do encontro do homem branco com o indígena, perpassando pela influência da religião católica na cultura dos nativos - que se configurou como arma ideológica para justificar a colonização e a barbárie que se impôs aos índios - buscar-se-à , no romance Maíra, a interpretação que o autor faz desse encontro de culturas. Por meio da análise da estrutura da obra, pretende-se buscar o que é interno a ela - o fator social.

Esta pesquisa aconteceu mediante a leitura e a análise de Maíra, de Darcy Ribeiro, bem como sua fortuna crítica, baseado nas leituras de Antonio Candido, Alfredo Bosi, Moacir Werneck de Castro, Antonio Houaiss, Carmen Junqueira, Walnice Nogueira Galvão, Erich Auerbach, Hermenegildo Bastos, Darcy Ribeiro, João Adolfo Hansen, Michael Löwy e Lúcia Sá segundo o pressuposto da crítica dialética que vê a obra como estruturação estética do processo social.

Maíra traz como principal tema o encontro do índio com o branco e não se detém nos aborígenes e no seu encontro catastrófico com os jesuítas, mas também em tudo que o envolve, como a morte do sagrado, a morte da cultura indígena, a identidade perdida que chega à dizimação de um povo.

\section{Análise histórica da colonização brasileira}

O conflito entre o europeu e os indígenas se deu em vários níveis, segundo Darcy Ribeiro. Predominantemente, no nível biótico, com as pestes trazidas pelo branco e que eram mortais para as populações indenes; no ecológico, pela disputa do território, das matas e riquezas; No nível econômico e social, pela escravização dos índios e mercantilização das relações de produção e no plano étnico-cultural, na formação de uma etnia nova que foi se unificando na língua e nos costumes: os índios, perdendo seu modo de viver gentílico, junto aos negros e os europeus.

Darcy Ribeiro, no seu livro, O Povo Brasileiro, vai dizer que os índios perceberam a chegada dos europeus como algo espantoso, mas compreensível, na visão mítica que eles tinham do mundo. Acreditavam ser gente do seu deus sol, o criador Maíra. No início da chegada dos portugueses, os índios tinham uma visão ingênua daquele povo, tanto que muitos deles embarcavam nas naus acreditando que seriam levados a Terra sem Males, morada de Maíra. Nos anos seguintes à colonização, essa 
visão idílica não se mantém e a destruição as bases de vida social indígena e a negação de seus valores, faz com que muitos índios preferissem a morte do que assistir a morte da sua cultura e de seu deus.

Sobre esses índios assombrados com o que lhes sucedia é que caiu a pregação missionária, como um flagelo. Com ela, os índios souberam que era por culpa sua, de sua iniqüidade, de seus pecados que o bom deus do céu caíra sobre eles, como um cão selvagem, ameaçando lançá-los para sempre nos infernos. $\mathrm{O}$ bem e o mal, a virtude e o pecado, o valor e a covardia, tudo se confundia, transtrocando o belo com o feio, o ruim com o bom. (RIBEIRO, 2007).

Na América, a catequese dos índios pelos jesuítas foi co-autora da imposição de um destino que se configurou como promessa civilizadora de emancipação. Ao mesmo tempo, a colonização não pode esconder sua face de barbárie, a qual também contou com a participação dos jesuítas, justificadores dos massacres aos indígenas. A isso não ficou alheia à literatura, que foi transplantada da metrópole portuguesa e funcionou como uma arma de imposição cultural e ideológica. Ideológica no sentido de justificar a colonização e a catequese, imprimindo um discurso de salvação do povo gentio pela fé.

Foi evidentemente nefasto o papel dos jesuítas, retirando os índios de suas aldeias dispersas para concentrá-los nas reduções, onde, além de servirem aos padres e não a si mesmos (...) eram facilmente vitimados pelas pragas de que eles próprios, sem querer, os contaminavam. (RIBEIRO, 2008, p. 51)

Além da catequese, a literatura, no período da colonização, foi usada para impor valores europeus aos povos primitivos, o que, segundo Antonio Candido, em Literatura de dois gumes, foi uma literatura que do ângulo político pode ser encarada como uma peça eficiente do processo colonizador,sendo de tal modo expressão da cultura do colonizador (CANDIDO, 1987). Houve uma forte restrição por parte da administração da colônia a uma possível expansão das culturas dominadas, e a língua geral da colôniao tupi-guarani- foi adaptado pelos jesuítas e ,na segunda metade do século XVIII, foi proibida, por um decreto de Marquês de Pombal, sendo rapidamente extinta. Estes exemplos ilustram como a identidade indígena foi aos poucos se perdendo em função da cultura européia.

A literatura desempenhou papel saliente nesse processo de imposição cultural, bastando lembrar que os cronistas, historiados, oradores e poetas dos primeiros séculos eram quase todos sacerdotes, juristas, funcionários, militares, senhores de terras-obviamente identificados aos valores sancionados da civilização metropolitana. Para eles as letras deviam exprimir a religião imposta aos 
primitivos e as normas políticas encarnadas na Monarquia; seriam uma forma de disciplina mental da Europa, que deveria ser aplicada ao meio rústico a modo de instrução e defesa da civilização (CANDIDO, 1987)

\section{Análise da obra}

Maíra, segundo Carmen Junqueira, é um poema. Poema que fala do mundo encantado dos índios mairuns, criado pelos Deuses Maíra e Micura. Trata-se também da morte desse Deus e do desencantamento de mundos.

Foi relacionando o índio com o mundo civilizado e pretendendo resgatar a história de Tiago Kegum Apoboreu, índio bororo tirado da tribo pelos missionários e catequizado em Roma, que Darcy Ribeiro escreveu Maíra- no romance- este está representado pelo personagem Isaías, que será analisado junto aos demais personagens neste trabalho.

Sobre a obra, o próprio autor diz:

O esquema de Maíra, em suas linhas gerais, já o definia como um romance da dor e do gozo de ser índio. Retomando ali, minhas memórias, consegui encarnar, dar vida, ao drama de Avá, uma espécie de índio-santo sofredor, na sua luta impossível para mudar de couro, deixando de ser sacerdote cristão para voltar à sua indianidade original. (RIBEIRO, 2007)

A opção do autor pela forma fictícia de narrar uma história real foi uma maneira de rememorar um real esquecido e dar conta de um discurso coletivo indígena, passando a voz do antropólogo para o principal personagem da história, que é o índio. O que é externo à obra, o fator social, torna-se interno, se torna estrutura. A literatura identificase com a vida, neste sentido.

Maíra mostra com profundidade o pensamento indígena, sua mitologia e seus costumes. $\mathrm{Na}$ introdução da edição comemorativa da obra, o autor diz que o melhor de escrever o romance foi ter feito como Homero, "retomando, compaginando, a mitologia de dezenas de povos indígenas", contrastando com a visão cristã do mundo, pois a doutrina religiosa, segundo Auerbach, tem a pretensão de uma verdade tirânica, "excluindo qualquer outra possibilidade de verdade". (AUERBACH, 2004, p. 13). Sendo assim, a religião recusa o mito e o excluí, o que aconteceu na catequização.

Maíra, para a cultura indígena, é um deus criador. O romance, intitulado com o nome do Deus, foi intencionalmente estruturado em forma de missa católica-Antífona, Homilia, Cânon e Corpus-mostrando a destruição que a catequese trouxe para esse povo, 
criando um paradoxo com seu deus da criação. Além disso, acolhido por esta estrutura, estão os modos de vida, os costumes, as crenças e os rituais indígenas.

Para cada uma dessas partes, dividem-se capítulos que alternam entre a voz do índio e voz do branco, a cultura do índio e a cultura do branco.

A linguagem religiosa perpassa a narrativa seja em sermões, rezas, e textos em latim retirados da Bíblia. No capítulo Verbo, que para a Igreja, representa a segunda pessoa da santíssima trindade, encarnada em Jesus Cristo, padre Xisto celebra uma missa e diz aos fiéis que a bíblia sagrada, assim como a fé, são a salvação daquele povo. Mais uma vez, em uma espécie de condicionamento que é dado com a repetição, aparece a imagem da salvação pela fé e este tema irá permear toda a narrativa.

Como acontece no capítulo $O$ Vômito, em que há trechos em latim transcritos da bíblia pelo pastor Bob. Este pastor, norte-americano, explica a Isaías, em um determinado momento da narrativa, que sua missão é enviar a palavra de Deus aos mairuns, e, os que dela quiserem aproveitar, serão salvos. Indagado por Isaías sobre seu povo mairum, Bob responde:

- Bem, os mairuns exigem outras técnicas. Eles são mais tarefa de Gertrudes, minha esposa. Ela é linguista, formada pela Bright University. Já tem algumas anotações da língua, que permitirão estabelecer sua estrutura fonética. Com mais alguns meses de trabalho, contará com material suficiente para levar a um glotólogo mais bem preparado que a ajudará a extrair a gramática. Este é o primeiro passo dos trabalhos com os mairuns. Trataremos, depois, de elaborar cartilhas de alfabetização para os índios e de alfabetizá-los. Assim, eles ficarão habilitados, progressivamente, para a civilização, através do instrumento básico de comunicação, que é a leitura. $\mathrm{O}$ importante porém é que, dado esse passo, eles terão acesso direto ao fundamento de todo saber verdadeiro, a leitura da Santa Bíblia que, então, estará traduzida em língua mairum. (p. 236).

Em Armagedon, capítulo composto por uma linguagem irônica, padre Xisto começa um sermão sobre o fim do mundo, avisando aos fiéis que se preparem para o desespero que se dará na Terra. Imbuído de grande sabedoria sobre a Bíblia, e inspirado pela voz de Deus, Xisto diz que haverá uma luta entre os justos e os pecadores, todos clamando por salvação. Ainda mais irônico, por parte do autor, é a fala de Xisto no final do capítulo:

O povo clamará por justiça, mas só verá subir aos céus, com suas vestes brancas, os missionários martirizados pelos índios nas selvas lá do Brasil brasileiro. Só eles se salvarão do pânico mortal, que descerá sobre o mundo antes que ele seja amortalhado com o manto-sudário do grande silêncio. (p. 320) 
Nota-se que há uma inversão de papéis, os missionários são os martirizados pelos índios, e não o contrário. E isto fica naturalizado na fala dos padres e na consciência dos fiéis.

Aparecem também, alguns trechos em que o Deus católico convive junto aos Deuses Mairum, o que Isaías vai chamar de "Deus de tantas caras"(p. 109). A reza de Isaías chama a atenção para o conflito de culturas que ele mantinha em si, conflitando crenças e mostrando que ele não pode ser só um, apenas, uma vez que já está internalizado duas identidades:

Meu Deus-Pai, criador do céu e da terra Meu Deus-Filho, Jesus Cristo, Nosso Senhor Morto na cruz,por vontade do Pai, para nos salvar (...) Minha Nossa Senhora: útero de Deus. Meu Deus-Pai, mairum: Maíra-Monan Meu Deus-Filho: Maíra-Coraci, Sol luminoso. (...)

Deus-Pai,Deus-Filho,Arcanjo Decaído Maria Santíssima, Açucena do Senhor Maíra-Manon, Maíra-Coraci,Micura Mosaingar: parida dos gêmeos de Deus Meu Deus de tantas caras, eu que tanto creio como descreio, peço a cada um e a todos; rezo e peço humildemente; Que eu não chegue lá, se não for de Tua vontade Que eu só chegue lá, se esta é a Tua vontade Mas, se chegar, que eu possa ser um entre todos Indistinguível.Indiferenciável. Inconfundível. Um índio mairum dentro do povo Mairum. (p. 109).

Maíra trás como principal tema o encontro do índio com o branco e não se detém nos aborígenes e no seu encontro catastrófico com os jesuítas, mas em tudo que o envolve como a morte do sagrado, a morte da cultura indígena, identidades perdidas até a dizimação de um povo.

Alfredo Bosi afirma que Maíra é uma lição sobre o convívio dos índios, que vivem coletivamente e "fazem da vida um bem comum", e que Darcy Ribeiro soube se apropriar deste universo dos índios por meio da beleza da arte na sua obra. Sobre esta lição, diz o crítico:

Ninguém é, intrinsecamente, superior a ninguém; ninguém é,intrinsecamente, inferior a ninguém: toda pretensa superioridade é uma usurpação. Se certas 
extrinsecalidades têm feito do homem o lobo do homem(...) esse caminho é o da morte de Maíra, da morte de Deus, da morte dos Mairuns, da morte da vida. (BOSI, 2007)

O romance é construído a partir de vários pontos de vista, que, segundo Luzia de Maria, são fragmentos de vários "eus", ao lado de um "eu" narrador, que é o sujeito do discurso, e compõe-se num caleidoscópio em que vários ângulos vai formando a imagem de um todo.

Isaías, ex Ava, personagem principal da história, busca a sua identidade perdida. Foi levado da tribo pela Ordem Missionária para ser catequizado e quer retornar e seguir com a tradição de seu povo, onde ele seria o tuxaua, o chefe da tribo. Mas, esse retorno se torna impossível, porque Isaías não pode ser branco e também não pode mais ser índio, é "coisa nenhuma” segundo ele.

Todos os homens nascem em Jerusalém. Eu também? Padre serei,ministro de Deus da igreja de Nosso Senhor Jesus Cristo. Mas gente, eu serei? Não, não sou ninguém. Melhor que seja padre ,assim poderei viver quieto e talvez até ajudar o próximo. Isto é, se o próximo deixar que um índio de merda o abençoe, o confesse, o perdoe.(p. 41)

Em Hebraico, Isaías significa “Deus é minha salvação”,um nome coerente para o personagem e de certa forma, contrastante com a sua realidade, pois ele não deveria ser salvo. E na verdade, não foi. O contato com o Deus causou em morte e não em salvação. Morte no sentido figurado, significando perda de algo maior que não a vida, perda da própria existência, da cultura e de tudo o que o caracteriza.

Semelhante a esse tema, ocorre no conto Meu tio o Iauaretê, de Guimarães Rosa, que narra a história de um mestiço de branco e índio e seu destino,de ser agregado de fazendeiro e enviado a desonçar o sertão. Iauaretê, em tupi, significa onça verdadeira, e indica a origem tribal do protagonista. No entanto, ele é levado a matar onças, negando seus ancestrais, e sua cultura formadora. Walnice Nogueira Galvão, em seu artigo sobre o conto vai dizer que o resultado disso é a perda de identidade, pois o personagem não sabe mais quem é, nem o que é, o que ocorre com Isaías. Nessa passagem do conto, nota-se o personagem dividido em duas culturas - a do pai branco e a da mãe índia - que, por não saber quem é, nem o que é, também não sabe seu nome:

Ah!, eu tenho todo nome. Nome meu minha mãe pôs: Bacuriquirepa. Breó, Beró, também. Pai meu me levou para o missionário. Batizou, batizou. Nome de Tonico, bonito, será? Antonho de Eiesús... Depois me chamaram de 
Macuncozo, nome era de um sítio que era de outro dono, é - um sítio que chamavam de Macuncozo... Agora, tenho nome nenhum, não careço. (p. 42)

No capítulo Retorno, em Maíra, Isaías planeja sua volta à tribo, mas logo percebe que este retornar é impossível diante da sua incapacidade física, do seu aniquilamento devido à doenças e outros acontecimentos. Percebe que sua alma não pode mais ser mairum, que sua cultura e seu passado foram desfeitos com o tempo. Apenas a sua vontade e sua esperança o animam a continuar com o retorno:

Como saí menino, mas fornido de ossos e coberto de carnes firmes, eles buscarão em mim a estatura que houvera tido se não fossem tantas pestes e asmas desses ásperos invernos romanos. Se não estivesse aí a minha memória para dizer-me que eu sou eu;se não estivesse aí tanta lembrança me vinculando ao que fui, eu mesmo não me reconheceria no homem esquálido, vergado, que volta para casa. Excetuando a memória que nos ata aos dois, que temos nós de comum? Meus idos poderiam ser de outro. Eu realizo a mais provável das minhas possibilidades. Nada tenho com o menino de então, ou quase nada. Com o homem que eu seria menos ainda. Sou apenas o desejo ardente de vir a ser um pouco do que poderia ter sido, se não fossem tantos desencontros. (p. 108)

Sob o ponto de vista do opressor, está o personagem Juca- mestiço, filho de mãe Mairum e pai branco. Este rejeita os costumes de sua tribo para ingressar no mundo dos caraíbas. Regressa à tribo anos mais tarde, rico e disposto a subjugar os parentes a um regime de semi-escravidão. A cena da sua chegada é assim descrita pelo autor:

Mal pôs os pés na praia, berrou: ei, minha gente, voltei! Fez desembarcar dois caixotes de querosene que tinham, por cima, tabaco cortado em nacos e rapaduras partidas e, do meio para baixo, cachaça. Seguiu pela vereda, atrás de Boca e Manelão ( seus empregados), que carregavam os caixotes. Advertia:

-Olha, Manelão, não quero confiança com as mulheres dos parentes. Estes Mairuns são matreiros. Fazê-los trabalhar é mais difícil que caçar onça com anzol. Hei de fazer. Chegou a hora deles. São meus parentes. Precisam produzir. (p. 47)

Juca, segundo Alfredo Bosi, "quer aproveitar o tempo e apossar-se do tempo dos índios para convertê-los em negócio e dinheiro”. (BOSI, 2007)

Darcy Ribeiro, em alguns momentos, faz o discurso do personagem Juca se assemelhar ao discurso do colonizador europeu, persuadindo os índios a trocarem mercadorias por serviços, começando pelo fumo e a cachaça- que viciava os nativos-, e passando para outros utensílios que lhes eram desnecessários:

Agora precisamos começar vida nova,meus parentes. Vocês precisam de muita coisa. Eu sei. Precisam de espingarda Rand, de terçado Matão, de enxada Jacaré, 
de tesoura União, de sal Mossoró, de fósforo marca Sol, de faca e anzol e linha de náilon e de muitas coisas mais. Estas coisas todas eu tenho. É só vocês quererem. É só trabalhar.

Mas agora não troco mais nada por pirarucu seco não. Agora, quero pele de lontra (p. 48)

No capítulo Regatão, Juca revela que seu pai pacificava índios e trocava com eles mercadorias por serviços, até que conseguiu enriquecer. Torna-se importante ressaltar sua fala nesta passagem do livro:

Naquele tempo tinha uma enormidade de índios por aí(...) Isso no tempo de meu pai, no meu tempo de menino já estava minguado! O que acabou com a indiada antiga foi o sarampo e a gripe, depois a gonorréia e essas doenças que eles ainda tem (p. 142).

Vê-se então, que a barbárie da colonização não se extinguiu por inteiro, e que deixou traços hereditários aos descendentes, e há uma perpetuação dos massacres, da violência e da maldade causados aos índios. Juca é apenas um reflexo fiel do pai.

Seu fim é trágico. Encontrado morto na Praia da Tapera com seus dois empregados. As investigações que foram feitas atribuem -sem provas- aos índios Xaepes a responsabilidade pelas mortes, o que justificaria ações de pacificação sobre esta tribo. Assim, Elias Pantaleão da Silva, o escrivão do ofício que comunica o acontecimento encerra:

Se me fosse dada a oportunidade de exarar um parecer sobre a matéria, eu opinaria que cumpre reiniciar, quanto antes, com os necessários recursos e como uma ação oficial, a cargo de um sertanista experimentado, as ações de pacificação do índios xaepes(...) (p. 356).

Esta condenação é arbitrária, mas, no entanto, como trata-se de uma autoridade e procura-se uma justificativa qualquer para que os índios sejam pacificados, é mais coerente atribuir-lhes a culpa e condená-los .

Há na narrativa diversos ângulos que se misturam, segundo Antonio Candido. Entre eles, o ângulo de Alma, a mulher branca e loura que procura desesperadamente ingressar no mundo do índio em busca de uma possível redenção.

Alma, por ser branca, pertence a uma classe privilegiada, o da cultura dominante. Faz parte do mundo do dominador. No entanto, por questões sociais, ela passa a ser dominada, oprimida. 
Sua vida é feita de troca, como uma mercadoria, por isso se envolve sexualmente com vários homens em troca de um apartamento, automóvel e injeções para aliviar as dores do pai doente.

Desagregada, tem uma vida vazia - condição que pertence ao civilizado - por estar inserida em um sistema capitalista, que automatiza as relações entre as pessoas.

Em um momento de desespero, procura buscar sua redenção, redimindo-se dos pecados e fugindo daquelas condições.

Sua única esperança é ingressar na ordem dos missionários e assim se refugiar na fé e encontrar a salvação dos seus pecados em Deus. "Não posso com favelas. Deus não cabe no meio de tanta fome, sexo e maconha" (pp:61). O Deus da salvação também não salva o seu mundo, não cabe nele. Nessa busca pela mudança, encontra Isaías e ambos chegam à tribo mairum. Têm os mesmos objetivos, cada um luta por um novo início da vida, um recomeço que os signifique.

Ingressando no mundo do índio, Alma rejeita o mundo civilizado do Rio de Janeiro onde ela também não conseguiu se encaixar. Vai assim, buscar a própria identidade junto aos índios.

A convivência com os indígenas a faz perceber que aquilo também não pertence à ela,pois não pode ser índio, não há como negar a sua antiga existência, por mais que a rejeite.

Em uma conversa com Isaías, confessa:

Comparado com o que sou agora, aqui, onde não sou ninguém, lá no Rio onde eu era muito mais, na verdade eu não era nada. Lá todos os que estão conscientes de si mesmos deveriam saber que são nada. Anulados no falso convívio estereotipado: "bom dia", "passe bem", muito prazer". Despossuídos de dons pessoais, a menos que seja cantora de fama, ou craque de futebol, o que pouca gente é. Despojados do saber que tanto cresceu e se dividiu que ninguém sabe se não bocadinhos, insignificâncias. Não há mais sabedoria. Desumanizados na frente da máquina de escrever ou do tear, batendo o que outro escreveu e tecendo o que outro desenhou. Não quero nada daquilo. Também não quero mairunizar-me completamente. (p. 329)

Nota-se uma crítica aos modos de vida da sociedade, em que os seres humanos, com o capitalismo, se desumanizaram frente à tecnologia.

O encontro de Isaías com Alma mostra diretamente o convívio do civilizado com o índio, ambos são iguais na sua procura e recebem a condenação na morte, no desencanto. 
Em convívio com seu povo mairum, Isaías então confirma suas suspeitas de que não sabe e não tem condições para se adequar. Não tem a força física que seu clã exige para suceder o chefe da tribo, não consegue caçar com flechas, e sim com espingarda e os hábitos não estão preservados, como andar nu, por exemplo. Não corresponde às expectativas dos mairuns, os quais, segundo ele, estão desejando uma espécie de milagre, "uma eclosão, que faça sair de dentro das suas poucas carnes, de dentro do seu corpo esquálido um outro ser: um onção vigoroso, maduro, respeitável, sábio, o chefe que esperam.”.

Interessante notar, em uma passagem do capítulo As Minhas águas, que Isaías, mesmo ingenuamente, carrega consigo os modos de vida e de produção capitalistas, os quais ele tentará aplicar na sua tribo. Conversando com Alma, é revelado seu grande projeto, aproveitando a quantidade de terras férteis da região, para formar uma plantação:

-Mas não quero saber de nenhuma roça mairum, com as plantas todas misturadas, crescendo como se fossem no mato. Sua roça será bem arrumada. Com tabuleiros só de milho, outros só de feijão ou de amendoim para crescer em ordem e para facilitar as grandes colheitas. A produção, vendida, permitirá comprar muitas coisas que serão distribuídas entre os que mais colaborarem.

O melhor do plano é a idéia inovadora de utilizar o élan desportivo e cerimonial dos mairuns, convertendo-o em força produtiva.(...) Os mairuns, explica, aplicam todo o vigor físico e intelectual- que poderiam colocar no esforço para progredir- na superelaboração de sua etiqueta social, cerimonial e esportiva. Trata-se ,agora, diz ele, de induzi-los a deslocar essas forças motivadoras para o setor econômico, a fim de promover o desenvolvimento.(p. 255)

O interesse pela monocultura e o desenvolvimento, corrobora sua inadequação naquela cultura indígena, pois os mairuns - e os índios em geral - não comercializam o que produzem e não há divisão de bens em suas comunidades,portanto, não há divisão de classes sociais. Sobre o plano de Isaías, interrompe Alma:

-Pra mim esses mairuns já fizeram a revolução-em liberdade. Não há ricos,nem pobres;quando a natureza está sovina, todos emagrecem; quando está dadivosa, todos engordam. Ninguém explora ninguém. Ninguém manda em ninguém. Não tem preço essa liberdade de trabalhar e folgar ao gosto de cada um. Depois, a vida é variada ,ninguém é burro, nem metido a besta. Para mim a Terra sem Males está aqui mesmo, agora. Nem brigar eles brigam. Só homem e mulher na fúria momentânea das ciumeiras. Deixa essa gente em paz, Isaías. Não complique as coisas, rapaz. (p. 256) 
É no capítulo Maíra-Avá que se percebe então o desajuste do índio Avá, ou Isaías. O deus Maíra, quer encarnar em algum dos Mairum para sentir novamente o seu mundo. Nota-se o seu desencanto logo no início do capítulo, antes mesmo de encarnar:

Daqui de cima,(...) olho e vejo. Vejo tudo. Lá de baixo todos me olham e me vêem com a luz que lhes dou, devolvida. (...) Olho e vejo, lá, este mundinho meu. Vejo água de mar e de rio. Vejo, também, lá no fundo, eles, o meu povinho Mairum.

Hoje quero entrar em alguém para sentir o mundo outra vez, com o corpo e espírito de gente vivente. Quero ver com os olhos que lhes dei.(...) Antigamente me dava mais gosto.Ainda me diverte, mas é pouco e cada vez menos. Alguma coisa falta a essas criaturas de meu Pai que tanto fiz para melhorar. Alguma coisa lhes falta, que será?

Aí está esse Avá que muito quis ser Isaías. Nele mergulho.” (p. 301)

Isaías, então, sobre ordem do Deus, fala sobre suas impressões naquele mundo que deveria ser seu:

Aqui estou nesta minha aldeia mairum, tão suspirada. Mas como é diferente, como ela é diferente, meu Deus. Como tudo é diferente do que eu esperava. É verdade que eu também não sou o mesmo. Não olho nada com os olhos de antigamente. Mas como tudo mudou! Eu mudei também, bem sei. O ruim é que não mudamos juntos, nem mudamos amadurecendo. Não sou quem devia, nem para mim, nem para ninguém, e pago todo o dia o preço de não ser (p. 301)

A imagem a que este trecho remete dá a narrativa a fiel condição do índio Avá, que é "o não ser", mostrando-se a ele todos os dias. Este "não ser", esta inconclusão do personagem, é o seu fim.

O fim da personagem Alma é igualmente significativo: tornando-se mirixorã dos índios, uma prostituta sagrada para eles, engravida de gêmeos pelo Deus Micura - o deus da criação, irmão de Maíra. No entanto, seus filhos nascem mortos, simbolizando a morte do Deus Mairum - anunciando a decadência indígena. A geração do Deus é interrompida assim e não há descendência.

Esta cena da morte dos gêmeos, que é conseqüência da morte da mãe, ocorre logo no primeiro capítulo do livro, A morta, anunciando o que será apresentado em todo romance.

A morte de Alma mostra a sua incompletude no mundo que tentou ingressar, como ocorreu com Isaías.

O cruzamento das histórias de Isaías e Alma, formaram, segundo Antonio Candido, a substância da linha narrativa central e mostra como Maíra é o livro de um 
antropólogo que assume plenamente a condição de escritor, ao fundir o conhecimento da vida primitiva com a experiência da civilização.(CANDIDO, 2007).

As diversas vozes e histórias que se cruzam na narrativa convergem-se para um capítulo final, no qual as vozes se misturam mais uma vez, mas sem identificação, como se mostrasse diversas consciências de uma coletividade formada por índios e brancos. Os capítulos Egosum e Indez, concluem a obra da maneira como ela se mostra desde o início, com o destino cruzado de todos os personagens da história.

\section{Considerações finais}

Este trabalho procurou, principalmente, investigar a religião católica, que se configurou como arma ideológica de imposição da cultura do Europeu sobre os indígenas com a missão de salvá-los a alma.

O desenvolvimento deste trabalho resultou em uma análise histórica e antropológica do Brasil, envolvendo as questões da formação do seu povo e o desaparecimento das nações indígenas em um mundo civilizado e influenciado pela religião católica.

Darcy Ribeiro, por meio da sua obra, reviveu uma história esquecida pela própria história do Brasil, que foi interpretada de diversas formas na literatura brasileira, dando continuidade da problemática no presente e, ao contrário de se pensar que há uma visão pessimista em relação aos índios e seu desaparecimento, o autor, com toda a experiência sobre a vida e os costumes indígenas que tem como antropólogo e amante desses povos, mostra com poesia as peculiaridades de uma cultura que não se tem conhecimento.

O povo mairum representa as diversas tribos indígenas que compõem o Brasil e seu resgate, é uma forma de revivê-los para a história. Por isso, Maíra é uma apologia à vida, que trás uma reflexão sobre o humano e dá o legítimo significado de uma imposição cultural, que se deu na catequização e continua existindo.

\section{Referências Bibliográficas:}

AUERBACH, Erich. Mimesis. São Paulo: Perspectiva, 2004.

CANDIDO, Antonio. A educação pela noite e outros ensaios. São Paulo: Ática,1987. 
.Formação da literatura brasileira. Belo Horizonte: Itatiaia,1981.

.Mundos Cruzados. In: . Maíra. Rio de Janeiro: 2007. p.381-385.

BOSI, Alfredo. Dialética da colonização. São Paulo: Companhia das Letras, 1992.

Morte, onde está tua vitória? In: . Maíra. Rio de Janeiro: 2007.p.387390.

CASTRO, Moacir Werneck de. Um livro-testemunho. In: Maíra. Rio de Janeiro: 2007.p.3911-392.

GALVÃO, Walnice Nogueira. O impossível retorno. In: Mínima Mímica: Ensaios sobre Guimarães Rosa. São Paulo: 2008.

HANSEN, João Adolfo. Anchieta: Poesia em Tupi e produção da alma. In: Moderno de nascença. Figurações críticas do Brasil. São Paulo: 2006.

HOUAISS, Antonio. Maíra. In: . Maíra. Rio de Janeiro: 2007.p.395-396

JUNQUEIRA, Carmen. Maíra. In: . Maíra. Rio de Janeiro: 2007.p.397-399

RIBEIRO, Darcy. Maíra. Rio de Janeiro: 2007

RIBEIRO, Darcy. O Povo brasileiro. São Paulo, 2006.

ROSA, João Guimarães. Meu tio o Iauaretê. In: Estas Estórias. Rio de Janeiro: 1969. 